\title{
THE MATTHEAN COMMUNITY ACCORDING TO THE BEGINNING OF HIS GOSPEL
}

\author{
F.P. Viljoen ${ }^{1}$
}

\begin{abstract}
The social setting of the Gospel according to Matthew remains a much debated issue. The theory of a gentile setting with historical roots within Judaism was met with much opposition in recent times. The expression "the parting of the ways" as introduced by Dunn and popularised by Stanton effectively marks this discussion. However, the relation between the Christian community of Matthew and Judaism remains a much debated issue. Some studies have argued that the Matthean community was sectarian in nature, being in conflict with a larger Jewish social context. From the Gospel it is clear that there was a struggle between the Matthean community and local Jewish communities and leaders. This indicates a distance between a Jewish background and a gentile presence within the community. Matthew views the new People of God as distinct from the nation which rejected Jesus as their Messiah. Within the discussion with regard to the Matthean community, the great commission (Matt. 28:18-20) is often seen as the key to understanding the whole book and particularly the community. However, the importance of the beginning of the Gospel is often neglected in this discussion. In this article I attempt to show the importance of the opening narrative in defining this community.
\end{abstract}

\section{INTRODUCTION}

Modern New Testament scholarship has focused a great deal on discerning the situation behind various writings. It is generally true that the New Testament documents are occasional writings. It should therefore be possible to reconstruct something of the situation which caused the author to write a particular document.

In a recent collection of essays, Bauckham (1998:48), however, argues that Gospels are more "open texts", requiring less locally specific information for correct understanding by implied readers than in the case of epistles. In the same line of thinking, Burridge (1998:113-145) states that Gospel writers most likely sought wider circulation than letter-writers. This obviously is the case and a reconstruction of the

1 Prof. F.P. Viljoen, School for Biblical Sciences and Biblical Languages, NorthWest University, (Potchefstroom campus), Potchefstroom, 2531, Republic of South Africa. E-mail: sbbfpv@puk.ac.za. 
situation should be easier in the case of letters, but even in the case of a Gospel it might be possible to suggest that an evangelist presents his narrative in a particular way because of certain tendencies in the church for which he is writing. Such suggestions should, however, be done with much caution. It should be taken into consideration that looking for Gospel audiences is not the same as reconstructing detailed communities. When using "community" in this article, not a single house-church or particular city is meant (as was done in traditional redactional assumptions); it should rather be understood in the sense of the target audience. Enough emphases can be identified that might be related to issues regarding the situation of the Gospel.

It has been increasingly recognised that the social context of Matthew is closely related to the author's relationship with Judaism (Keener 1999:45; Viljoen 2005:1). Matthew intensifies the conflict in the narratives he took over from Mark (Repschinski 2000:63ff.). It seems as if a specifically Pharisaic component of some sort was competing with the early Christians for influence over popular thought (Keener 1999: 46). Matthew clearly identifies the Jewish leaders as Jesus' opponents, while the crowds often serve as the audience of these conflicts. Matthew represents Jesus as the undisputed victor in all these contests. The controversies demonstrate a derogation of the Jewish leadership, which suggests that Jesus and his opponents are both competing for the leadership of the crowds.

This heightened conflict with the Pharisees reveals something of the circumstances of the community in which Matthew is writing. Matthew's gospel fits within the complex history of Jewish-Christian relations in the first century.

Matthew intends the audience of the controversy stories to reflect a group that turns form the fraudulent leadership of the opponents of Jesus towards an acknowledgement of the Matthean community as the rightful leaders of Israel (Repschinski 2000:329).

The Jewish leaders are depicted as negative "types" provided for the edification of Matthew's community.

Perhaps the central problem in the study of Matthew's Gospel is how to interpret the apparently inconsistent attitude towards Judaism which the Gospel displays. Words like "paradox", "tension" and even "contradiction" regularly appear in discussions (see France 1998:95). The 
question arises whether Matthew's Pharisees reflect the situation of contemporary Judaism (Strecker 1971:16).

The aim of this article is to investigate the kind of life setting which might produce such a paradoxical document and to demonstrate how the beginning of the Gospel sheds light in this issue.

\section{MATTHEW AND JEWISH CHRISTIANITY}

Since the classic study of Daniélou on the theology of Jewish Christianity (1964), the definition of the term "Jewish-Christian" has been controversial. This definition does not focus on a sociological category, but on a theological tendency. It is therefore important to recognise that in first-century Christianity there was not necessarily a relation between Christians' ethnic or cultural origin and their theological position. Some Christians of Jewish origin (such as the Ebionites) remained more Jewish than Christian, while others scandalised these more conservatives by their emancipation of the law. On the other hand Gentile Christians could become more "Jewish" than Christians of Jewish origin.

For the purpose of this discussion it is therefore not necessary to get involved into the debate of the geographical location of the origin of this Gospel. Most arguments to pinpoint a location are based on locations which best would fit into the Jewish character of the Gospel. From the variety of opinions it is clear that there is no scholarly consensus on this issue (cf. Davies \& Allison 2004:138-139; Luz 1990:91f.). ${ }^{2}$

2 According to patristic tradition, Matthew's Gospel was written in Palestine (Van Bruggen 1998:57). However, this patristic location seems to be no more than an obvious guess for a Gospel with such a strong Jewish character. Many scholars today rather opt for the origin of the Gospel somewhere in Syria. This view can be traced back to the classic proposal of Streeter for the case of an origin in Antioch (Streeter 1924:500-527). According to Acts 11:26, the followers of Jesus in Antioch were called Christians for the first time. According to Acts 13:1-3, they were mission-minded as they were the church who sent Paul and Barnabas on their first missionary journey. Although not all Streeter's arguments are compelling, the general suitability of a church in Syria may be accepted (Kilpatrick 1946:131-134). However, there were strong Jewish communities in other parts of the Roman Empire as well, such as in Alexandria. Brandon (1951:217-243), for example, viewed Matthew as the expression of the Jewish-Christian commu- 
The general view that Matthew belongs to a Jewish Christian context has been supported by noting some of its emphases and distinctive linguistic and cultural features (Davies \& Allison 2004:138; Luz 1990: 79; Versteeg 1992:13). However, Matthew's Gospel reveals undoubtedly hostility towards non-Christian Judaism, together with an approval of gentile mission. The question is whether such an attitude is not more understandable in the case of a Jewish Christian who finds himself in a community increasingly cut off from his cultural roots, and who realises that the purpose of God is now worked out on an international scale.

\section{INTRA MUROS OR EXTRA MUROS?}

Much discussion has centred on the question whether the breach between the Matthean community and non-Christian Judaism has become so complete that the two communities had an attitude of mutual hostility and rejection towards one another. The expression "the parting of the ways" as introduced by Dunn $(1980 ; 1991)$ and popularised by Stanton (1983; 1992:99-116) effectively marks this discussion. Stanton provides a careful analysis of whether the debate with Judaism was being conducted intra muros or extra muros. It is often assumed that the transition between these two phases must be linked to the introduction of the Birkath ha-Minim ${ }^{3}$ around AD 85 (e.g., Burridge 1994:91). It is relatively sure that Matthew was composed in the general period in which this Jewish benediction which had a significant impact upon Jewish-Christian relations was first formulated (Horbury 1982:19-61).

While the "inside/outside" debate has widely been going on in recent discussions, Stanton's survey provokes doubts whether this is the right way to put the question. Furthermore it is reasonable to ask

nity in Alexandria. Even more suggestions for the place of origin for the Gospel have been made, such as Caesarea or in Transjordan (see Keener 1999:41f.; Stanton 1985:1942).

3 The so called Birkath ha-Minim was introduced into the Jewish synagogue liturgy, referring to a phrase in the Eighteen Benedictions which were supposed to be recited three times a day by all Jews:

Let Nazarenes (Christians) and minim (heretics) perish in a moment, let them be blotted out of the book of the living, and let them not be written with the righteous (as quoted by France 1998:85). 
whether designating the beginning of the antagonism specifically to AD 85 is not oversimplified. It is possible that hostility towards the synagogue might have developed and expressed itself in the language of mutual rejection even long before the Christian group ceased thinking of themselves as part of Judaism. It is highly unlikely that the transition to "outside" was a once-for-all development involving the whole Jewish-Christian movement at once. The view of Stendahl seems to be much more probable. The blending of Jewish and Hellenistic elements in Matthew's gospel is "a witness to a far smoother transition from Judaism to Christianity than we usually suppose" (Stendahl 1968:xiii-xiv).

The "inside/outside" debate should thus be regarded as artificial, based on an unrealistic understanding of the development of Jewish-Christian relations in the first century. To assume that the introduction of the Birkath ha Minim represented the beginning of a total new situation, before which the relations between Jews and Christians were relatively untroubled, and after which no meaningful contact was possible, is too simple. A tension was inevitable for any Jew who followed Jesus, and would lead to the sort of inconsistency one finds in Matthew's attitude towards the feindliche Brïder (Hummel 1966:55). Mohrlang speaks of Matthew's "dual citizenship" as both Jew and as a Christian.

Matthew belongs simultaneously to two different communities and traditions (Jewish and Christian) ... they are a community in transition (Mohrlang 1984:131).

\section{THE "GENTILE BIAS” AND AUTHORSHIP OF MATTHEW}

The "anti-Jewishness" of Matthew's Gospel has been noticed by most interpreters. A more recent development is the emergence of the view that the author of the Gospel could not have been a Jew, and that he was not writing for Jews. This view initially was proposed by Clark in his article "The Gentile bias in Matthew" (1947:165-172), and was followed by scholars such as Nepper-Christensen (1958:202-208) and Strecker (1971:15-35). The hostility towards "Judaism" and a favourable attitude towards Gentile mission lie behind most of these suggestions.

Other scholars, however, who are no less aware of these characteristics of the Gospel, have no difficulty in suggesting a Jewish-Christian 
setting. Hare, for example, presents a sharp description of the "antiJewishness" of Matthew's Gospel: "the invitation which Israel has refused so rudely is now to be offered exclusively to the Gentiles" which "assumes the abandonment of the mission to Israel" (Hare 1967:147148), however places the Gospel in a Jewish-Christian setting. Stanton (1977:67-83) offers a parallel view and also places Matthew in a JewishChristian milieu. Luz (1990:79) views the anti-Jewishness rather as argument for a Jewish-Christian setting:

It is to be expected especially of Jewish Christians that they would carry on with great intensity the debate with the synagogue, which remained far from Jesus, and would arrive at a severe judgment on Israel.

Luz further substantiates this argument by indicating the strong influence of Matthew's Gospel on several Jewish-Christian writings (Luz 1990:81).

Taking the paradox of the "Jewish" and "anti-Jewish" characteristics of Matthew's Gospel into account, the more plausible explanation therefore remains that the author was writing in the painful situation of a Jew who followed Jesus and therefore experienced increasing tension with official Judaism. The author realised that the purpose of God in fulfilling the Old Testament promises was to be discerned on a wider front than only ethnic Israel. Though Matthew's primary audience was Jewish-Christians, this does not imply that it excluded Gentile converts.

\section{GENTILE MISSION}

From the discussion thus far it becomes clear that the Gospel of Matthew comes from a situation in which the Jewish-Christian community stood at a turning point. The destruction of Jerusalem in the Jewish War could have been experienced by the Jewish-Christian community as the judgment of God on Israel. These circumstances could have provoked the community to carry the proclamation of Jesus to the Gentiles. This decision must have been controversial in the Jewish community. In a Hellenistic culture within the Roman Empire the Jews struggled to maintain their unique identity. This resulted in a strong tendency towards exclusiveness - even more so in the synagogue. In contrast to this exclusivity, the Matthean community advocated Gentile mission. This created much tension with the synagogue (Repschinski 
2000:27). The conflict with the synagogue indicates that the community was heading towards a break with the contemporary Judaism of the synagogue. Luz (1990:84) proposes that Matthew elected himself as advocate to defend his community's decision for the Gentile mission. ${ }^{4}$

\section{FUNCTION OF THE BEGINNING OF A NARRATIVE}

The intra or extra muros scholarly discussion of the Matthean community, its relation with the Jewish community and gentile mission, was to a large extent influenced by the assumption by many scholars that the great commission (Matt. 28:18-20) should be regarded as the key to the understanding of Matthew's narrative. This implies that the Gospel actually needs to be read backwards from the great commission as the climactic text in the Gospel. This was proposed by Michel in 1950 and has since become one of the mainstays of the interpretation of Matthew:

Ja, der Abschluss ... lehrt das ganze Evangelium, die Geschichte Jesu, "von hinten her" zu verstehen. Matth. 28:18-20 is der Schlüssel zum Verständnis des ganzen Buches (Michel 1950:21).

France (1993:316) writes:

Thus the temporary restriction of the period of Jesus' ministry $(10: 5-5 ; 15: 24)$ is swept aside, and the insistent indication throughout the Gospel that Jesus is more than merely the Messiah of Israel are focused in the command from now on to make disciples of all nations.

However, with these kinds of assumptions, Repschinski (2004:3) demonstrates with reference to Aristotle's Ars Rhetorica that too little emphasis is placed on the beginning of the narrative. Speaking of the троó $\mu \iota$ of forensic speeches, Aristotle defines the function in analogy with other genres as providing

a sample of the subject, in order that the hearers may know beforehand what it is about, and that the mind may not be kept in sus-

4 According to Luz (1990:84), this new venture is shown by a fracture between the "commission of the risen Lord" (Matt. 28:19f.) and of the "earthly Jesus" (Matt. 10:5f.). The sharp differentiation between the "risen Lord" and "earthly Jesus", however, is debatable (cf. Viljoen 2002:555-572). 
pense, for that which is undefined leads astray; so then he who puts the beginning ... into the hearer's hand enables him ... to follow the story ... So then the essential and special function of the exordium is to make clear what is the end or purpose of the speech (Aristotle, Ars Rhetorica III. 14.5-6).

Surely the Gospels cannot exactly be defined as ancient speeches (Burridge 1995). ${ }^{5}$ However, the parallel with regard to the beginnings of each story or speech is significant. The study of the Gospels as narrative has enjoyed renewed attention since the late 1970s. It is realised that one of the things that is often lost when studying a Gospel is that it is a narrative, presenting a sequenced story (Bock 2002:206). In line with such a narrative approach, modern literary theory has dealt with the functions of narrative beginnings. Findings from these studies confirm

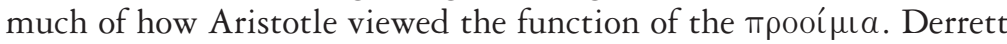
(1975:81) writes that reading the beginning prepares for the "hearing the Gospels as a whole". Beginnings provide the reader with an opening into the world of the text which allows him/her to progressively orient himself with it (Rabinowitz 1987:58). They act as markers of space, time, themes, topics and characters. These markers are tentative and are in need of development within the narrative (Repschinski 2004:4). The tentativeness of these markers invites the reader into the story and sharpens his/her expectation for the development of these markers within the story. Thus the beginnings awaken within the reader a predisposition for understanding the text. This means creating an implied reader who can serve as appropriate recipient of the text. Howell (1990:115) even describes this as the "education of the reader". Aristotle calls the function

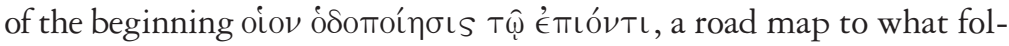
lows (Ars Rhetorica III. 14.1).

\section{THE INFANCY NARRATIVES AS EXORDIUM OF MATTHEW}

Thus far it is suggested that the beginning of Matthew plays an important role in the development of the story throughout Matthew's Gospel. At the beginning Matthew endeavours to point out the chief

5 Burridge discusses the question "What are the Gospels?" in the light of modern literary theory and classical literature. 
theological concerns of his Gospel. Christology and the way of salvation from Israel to the Gentiles are in the foreground (Luz 1990:100). Motives and themes are set, which are being picked up later and then being intensified. Thus he writes about the Messiah of Israel, the Son of David $(1: 6,16,18-25)$, the coming of the Messiah to the gentiles $(1: 1,13-15,22)$, the rejection by Israel which is being foreshadowed $(2: 1-12,16-18)$ and Jesus as the Son of God $(1: 21 ; 2: 15)$. Thus the infancy narrative (Matt. 1 and 2) may be designated as a thematic prelude of the Gospel, similar to the exordium in classical rhetorical speeches.

Chapters 1 and 2 form a close-knit unit. ${ }^{6}$ On structural and narratological bases Luz (1990:102) even suggests that these narratives seemed to have formed a unit before Matthew. They represent a narrative type that recounts the announcement, persecution and rescue of the "royal child" which was common in ancient times (Davies \& Allison 2004: 209; Luz 1990:129). Especially the connection of this narrative to the Haggadah of the child Moses is noticeable.

\section{GENEALOGY OF JESUS (1:1-17)}

Keeping the function of beginnings in mind, the question arises what the significance is of the genealogy as introit to the Gospel. Matthew puts several accents on the traditional genealogy. Two of them are illuminated by the title: "Jesus is son of David and son of Abraham".

Firstly, Jesus is put in the continuity of the history of Israel as the Messiah of Israel. It is emphasised that Jesus is the King of Israel. For this reason verse 6 sets apart David as king. Jesus then becomes the counterpart of king Herod in 2:1-12. In 21:5 he will enter Jerusalem as the other, but humble king (Luz 1990:109). Matthew thus provides a prelude for this important theme of his Gospel: Jesus is the Messiah of Israel.

Secondly, the title mentions Jesus' descent from Abraham. Does this say more than the obvious that Jesus is a Jew? Luz (1990:109) suggests that one may find so much in his interpretation of the four ancestral

6 Many commentators draw a decisive line between die genealogy (1:1-17) and the Matthean birth narrative (1:18-2:25). However it should be recognised that the whole of chapter 1 has its own integrity and that the demarcation rather lies between the two chapters. 
mothers ${ }^{7}$ that are mentioned: Tamar (vs. 3), Rahab and Ruth (vs. 5) and the wife of Uriah (vs. 6). ${ }^{8}$ The common denominator for these women is found in the fact that they all represent an "irregularity" in the Davidic line. Stendahl (1995:74) demonstrates that by this irregularity the action of God and the Spirit is made manifest. It was often suggested that they were placed in the genealogy as sinners in order that the grace of God may become visible with them. ${ }^{9}$ This thought is attractive in the case of Bathsheba to whose adultery the words "Iriah's wife" would point, although it seems as if the text is more interested in the sin of David than the sin of Bathsheba. However, it is impossible with Ruth, on whom there is no blemish, according to Jewish tradition. Even Rahab and Tamar were celebrated as symbols of virtue (Davies \& Allison 2004:171). It is more likely that the author wanted to point out that al four women were non-Jews.

Thus the genealogy suggests an inclusive connotation. It indicated that the son of David, the Messiah of Israel, brings salvation to the Gentiles. The opening of the salvation of Israel to the Gentiles becomes a predominant theme in the Gospel of Matthew. This makes the interpretation of the words "son of Abraham" even more striking. According to broad Jewish tradition, Abraham was regarded as the father of the proselytes $^{10}$ (Davies \& Allison 2004:158; Luz 1990:110).

The third accent which Matthew imposed on the genealogy is found in verse 17 . The evangelist divides the genealogy into three times fourteen generations. Although there is no ready explanation for the number fourteen (Luz 1990:110), it seems to indicate that Jesus is part of an ongoing divine plan.

7 Women usually were not mentioned in Jewish genealogies (Davies \& Allison 2004:170).

8 At the same time it is remarkable that the three great Jewish female personalities are missing: Sarah, Rebecca and Rachel.

9 Jerome suggested in his commentary on 1:3: "ut ... peccatoribus nascens omnium peccata deleret" (That (Christ) being descended from sinners, might destroy the sins of all). John Chrysostom 3,2 wrote: "[O]ne must not hide the wickedness of the ancestors, seek one's own virtue, and not boast of others merits".

10 Probably alluded to in Gen. $12: 1-3 ; 17: 5 ; 18: 8$ 
It is clear that the genealogy as introduction to the Gospel identifies Jesus, the Son of David, as the Messiah who fulfils the plan of God. He does not only attend to the Jewish people, but also reckons with the gentiles. Thus the reader is alerted to be observant of the development of these markers in the rest of the story.

\section{JOSEPH TAKES MARY TO BE HIS WIFE}

$$
(1: 18-25)
$$

The next part of the introduction is Matthew's account of how Joseph takes Mary to be his wife after the appearance of an angel to him in

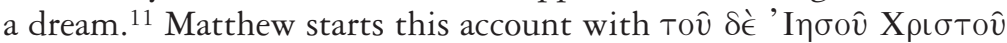
$\dot{\eta} \gamma \in \dot{\epsilon} \nu \in \sigma \mathrm{s}$. The term $\gamma \in \dot{\epsilon} \nu \in \sigma \mathrm{\iota s}$ apparently refers to the birth of Jesus, which would mark this pericope, as Hagner (1993:15) demonstrates, as a proper birth narrative. However some scholars, such as Luz (1990: 118) and Stendahl (1995:74), argue that this term rather connects this pericope with verse 1 as explanation of verse 16 . Thus it seems likely that Matthew views the conception, Joseph's decision to separate from Mary, and the dream as part of the story of origins (Bí $\beta \lambda o s \quad \gamma \in \nu \in \epsilon \sigma \in \omega S$ - 1:1) which began with the genealogy, more or less functioning as an enlarged footnote to the genealogy. In 1:18a the expectation is raised that an explanation will be given of the curious statement in 1:16 that, although Jesus is not the child of Joseph, He is through him the son of David. Matthew answers this question in sober language by stating that Mary was pregnant through the Holy Spirit. Equally sober he tells that Joseph decided to separate from Mary. In 1:20 the reader's attention is heightened by the interjection ioov as the angel appears in the narrative (Luz 1990:115). This interjection which points to a thing unexpected (Davies \& Allison 2004:205) draws the attention to the message which the angel brings.

The first part of the message (1:20) connects the dream to the genealogy. The message that Mary was pregnant through the Holy Spirit was new to Joseph, although for the reader it is merely a reminder of what Matthew already told in 1:18. In the second part of the annunciation the reader receives new information (1:21). Repschinski (2004:6)

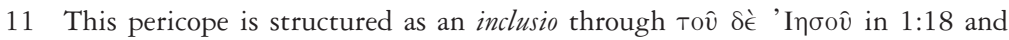
'I 
indicates that the weight of this second part is marked by the change of direction in the narrative. The first part looked back into the past, the $\gamma^{\prime} \in \in \in \sigma$ IS of Jesus. Joseph therefore should not be afraid to take Mary as his wife. In the second part of the announcement the attention is turned towards the future. The angel makes three statements with regard to what will happen in the future. These three statements are constructed in a parallelism:

- Of Mary is said that she would give birth to a son

- Of Joseph is said that he would give the son the name Jesus

- And of Jesus is said that he would save his people of their sins.

Within the scope of the pericope (in Matt. 1:25) the first two statements are being fulfilled. This leaves the reader in suspense with the third statement of the angel. This statement becomes a marker in the narrative (Repschinski 2004:7). Thus the reader is alerted to be observant of the development of this statement in the rest of the story.

For the reader to discover what exactly the meaning of the angel's third prophecy means, the text provides some markers. The first of these is that the name must be Jesus because of his saving activity. By word

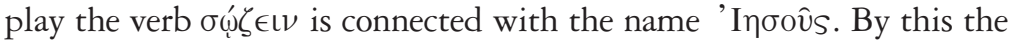
reader is guided to understanding Jesus' life of saving activity. ${ }^{12} \mathrm{~A}$ second marker is provided by the object of this activity, Tòv $\lambda a$ òv $a \dot{v}$ -

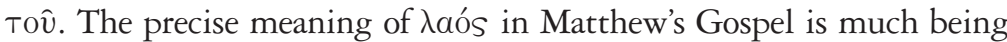
debated. Some scholars argue that it always means the people of Israel (e.g., Luz 1990:121). Many commentators favour the view that Matthew here intends a new people of God, the church (Davies \& Allison 2004: 211) — with reference to Psalm 130:8 (LXX 129:8). This statement presents the reader with the challenge of tracing the actual ways of how this salvation is realised in the life or Jesus.

The importance of personal names in Matthew 1 is obvious. Stendahl (1995:73) even describes Matthew 1:18-25 as a legend of divine name giving. The revelation of the angel and Joseph's obedient answer forms the nucleus of the pericope.

12 Strangely throughout the Gospel Matthew prefers the verb á tion with the forgiveness of sins. Matthew probably used $\sigma \omega \varphi_{1} \zeta \in t \nu$ here because of the word play with the name Jesus. 


\section{GEOGRAPHICAL ITINERARY (MATT. 2)}

Already in 1960 Stendahl, in his article Quis et Unde? An analysis of Matthew (reprinted 1995), pointed out how Matthew 2 is dominated by geographical names (1995:71). This is even more striking in contrast to chapter 1 , which has no single one. The chapter begins with Bethlehem of Judea, then takes the reader to Egypt, then describes the massacre at Bethlehem, takes the reader out to Egypt back to the land of Israel, bypasses Judea, takes one into Galilee and settles down in Nazareth. Clearly this itinerary is intentional. These geographical names indicate what is really important for Matthew's narrative. This is iterated by Matthew's substantiation of these geographical names by formula quotations (Matt. 2:6 and 2:15). Obviously this geographical information provides the structure of Matthew 2, but also of the "Christological geography" of the Gospel. Read as part of the exordium of Matthew's Gospel they also give prominent markers for the further development of the plot.

Once it has been recognised that Matthew 2 is focused on geographical names, the relation to Matthew 1 becomes significant. Chapter 1 focuses on personal names while chapter 2 focuses on geographical names. In both cases these names serve an apologetic purpose of describing the way of salvation beyond Israel to the Gentiles.

\section{GENTILE ASTROLOGERS FROM THE EAST}

$$
(2: 1-12)
$$

The narrative is divided into two main parts, namely the astrologers' encounter with the "false king" Herod in Jerusalem and the "genuine" royal child in Bethlehem. The narrative describes a conflict. On the one side there is the evil strategy of Herod in Jerusalem (and all Jerusalem with him), and on the other side the good strategy of God to bring the astrologers to Jesus. Matthew's intentional depiction of Herod and the whole people of Jerusalem together belonging to the front that rejects the royal child, seriously comes as a surprise. Historically it is well known that Herod was so unpopular with the Jerusalem inhabitants that news of a royal child and especially a messianic child would have caused great joy. This unexpected information surely serves as a marker for the development of the rest of the plot. Matthew gives a signal to that which is to take place later in the narrative. 


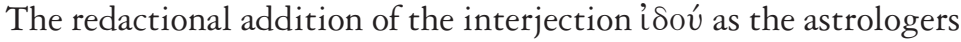
enter the story, once again arouses attention (Davies \& Allison 2004: 227) putting them very much in the centre of the plot. In answer to the astrologers' question where to find the royal child, the scribes answer with Micah 5:1. Matthew here - in the mouth of the scribes avoids the fulfilment formula. Although they recognise the events as part of the expected Messiah, they did not draw the consequences. Instead they became indirect companions of Herod. In contrast to the scribes, the astrologers found the child and as climax of the story threw themselves on the floor in worship of the child. The implied reader is thus expected to identify with the astrologers.

Many scholars, such as Daniélou (1964:490), are of the opinion that the astrologers (as the shepherds in Luke ${ }^{13}$ ) were mere inventions of Matthew and that they are merely a figuration of the admission of the gentiles into the church. While this assumption is disputable, the narrative clearly reflects on the admission of gentiles into the church. The midrashic connection between the visit of the astrologers to Jesus and the brothers of Joseph of antiquity is significant (Derrett 1975:103). The astrologers bowed down before Jesus as the family of the ancient Joseph bowed before him (Gen. 42). What was expected of God's own people was done by strangers. This fits into the strategy of God.

Matthew tells how the gospel will be spread amongst the heathen. The astrologers are regarded as the primitiae gentium (the first fruits of the Gentiles) ${ }^{14}$ taking up the similar concern of the genealogy with an accent of anti-Jewishness. The adoration of the child by the gentiles implies the damnatio Iudaiorum (condemnation of the Jews) ${ }^{15}$ (Luz 1990: 133). After the death and resurrection of Jesus God would be worshiped in all parts of the then known world according to the pattern of the worship of the baby by the astrologers.

13 The contacts with the Lukan birth narrative are minimal and at this point these traditions clearly are different.

14 This formulation as interpretation of the text probably was first used by Augustine, Serm. 200.1 and 202.1.

15 The anti-Jewish elements of the text are brought out by John Chrysostom 6.3. 


\section{HEROD, THE FLIGHT TO EGYPT AND RETURN TO NAZARETH (2:13-23)}

The two-stage return of the family of Jesus in this pericope is significant. This pericope is divided into three subsections or episodes (vv. 13-15, 16-18 and 19-23) which each ends with a formula quotation showing some symmetry (Davies \& Allison 2004:259). The first and the third sections are formulated in parallel. In both sections the command of the angel and the description of its execution by Joseph are almost identical.

It has been suggested by Schlatter (1963:25) that, where "the struggle of the King against the Messiah" is described, language is used which draws on a similar motif in Exodus (Ex. 4:18ff.). Luz demonstrates that this material has numerous parallels in ancient stories of the persecution and preservation of the royal child which he regards as background to this story (Luz 1990:152-155). This assumption is strengthened by the mentioning of Herod's name nine times, and at all points of progress, even after his death (Matt. 2:22).

In the first episode (Matt. 2:13-15), where the typical redactional interjection íov again appears, the introductory formula to the quotation $\pi \lambda \eta \rho{ }^{\prime} \omega$ indicates the progress in the divine plan. In this formula God speaks of his Son. Luz (1990:146) demonstrates that this title, being the only Christological title in the whole of chapter 2, is extraordinary important for Matthew. In this passage the title is still undeveloped but already has a compository function in the Gospel. It functions as pointer to Matthew 3:13-4:11 where the conception of the Sonship of God is developed. In the quotation the Israel typology is connected to the title Son. The implication is that the exodus from Egypt is repeated and completed in Jesus. "Egypt" and "Son" serve as catchwords and surely should be recognised as markers for the development of the plot.

Luz (1990:143) draws attention to the distinctive position taken by the midsection (Matt. 2:16-18) of this pericope. As in Matthew 2: 1-12 the enemy of God, Herod, is active. The fact that even the evil action of Herod is concluded by a quotation formula points to the significance of this action. Herod cannot be regarded as true kind of the Jews if he kills Israel's children because of Jesus. In a similar way Matthew later would interpret Israel's rejection of Jesus as a contradiction of its 
favoured position. The mourning of the ancestral mother becomes a proleptic marker for the development of Matthew's narrative.

In the third episode (Matt. 2:19-23) the quotation formula ${ }^{16}$ once again plays a vital role and serves as another marker of what would later be developed in Matthew's Gospel. Jesus would be called a Nazarene. How Matthew understood Nazarene is peculiar as he links it to Nazareth, Jesus' place of living. Matthew locates Nazareth in "Galilee of the Gentiles" (Matt. 4:15). This geographical statement anticipates the way of the Messiah of Israel to the Gentiles. The term Nazarene (already being part of the pre-Matthean tradition within the community) is significant in the Syrian context (Davies \& Allison 2004:276). A Nazarean was the designation for Jesus and his followers (Luz 1990: 150). Since Jesus came from Nazareth in the Galilee of the Gentiles, he became a Nazarene, the teacher and Lord of the community who believes in him (Christians).

This section too presents essential statements as narrative markers to the whole Gospel as a foundational story of the coming of salvation in an anticipatory way.

\section{DEVELOPMENT OF THE THEME}

Matthew's concerns were clearly stated in the infancy narratives which serve as narrative markers. These narrative markers in the beginning of the Gospel are unfolded in the rest of the Gospel. Thus the reader is alerted to be observant of the development of these markers in the rest of the story. Strong emphasis is laid on the kingship of Jesus. The notion of Jesus being Saviour also of the gentiles is implicit in the names in the genealogy and announcement of the angel (Matt. 1). This concern of Matthew is continued by geographical interests in Matthew 2. This is enforced by the visit by the astrologers and the enmity of Herod and the Jewish leaders. The fulfilment citations underscore these concerns even further.

The following examples illustrate how these markers are developed through the rest of the Gospel:

16 The quotation cannot be identified in the Old Testament and the meaning of the term "Nazarene" is unclear. 
- When Jesus sends out the twelve apostles on their mission (Matt. 10), he orders them not to go among the gentiles or enter any town of the Samaritans, but to go to the house of Israel. Nevertheless, the Gospel indicates that the house of Israel rejected Jesus while the gentiles eventually accepted him.

- When the Canaanite woman begs Jesus to cure her daughter (Matt. 15:21ff.), Jesus initially quite sternly rejects her request stating that he was sent to the house of Israel, and to them alone. However, the woman's faith was so strong that Jesus eventually granted her request. Her faith stands in sharp contrast to the growing opposition against Jesus by the Jewish religious leaders.

- The opposition of the Jews led to Jesus' seven woes (Matt. 23) against Jerusalem and its religious leadership.

- When Jesus appeared before the Roman governor Pilate (Matt. 27), he realised that the charges against Jesus were laid out of malice (27:11ff.). Pilate found Jesus without guilt and washed his hands in full view of the people declaring that his hands were clean of Jesus' blood, but the Jewish people cried that his blood would be upon them and their children. The change from the use of óx $\lambda$ os referring to the crowd before Pilate to גaós in 27:25 suggests sharp irony. The death of Jesus is laid on Israel's doorstep. The Jewish people acknowledge their responsibility for the death of Jesus while the Roman governor distances himself from it.

- The Roman centurion and his men who were keeping watch over Jesus on the cross and saw the earthquake were filled with awe and they said: "Truly this man was a son of God" (27:54).

- When the Roman guards reported the empty grave to the chief priests, the chief priests offered them a substantial bribe to say that his disciples came by night and stole Jesus' body while they were asleep (Matt. 28:11-15). This might refer to the story spread in Jewish circles in Matthew's time.

- The climax of the Gospel is reached with the great commission (Matt. 28:19), where the resurrected Jesus commissions his eleven disciples to go out to the gentiles to make them his disciples. 
The flow of argument is clear: what actually was expected of Israel is done by the gentiles. The Gentiles accept Jesus to be their Saviour while the Jews reject Him.

\section{CONCLUSION}

The discussion in this article thus suggests a setting of the Gospel in early Christianity. On the one hand it is late enough to demonstrate a clear distinction and even hostility between the Jewish-Christian community and Judaism, but on the other hand early enough that the relation between these two communities is still a live issue.

Matthew's Gospel, viewed from the beginning to the end rather than from the end to the beginning, implies a reader who is rooted in the traditions of Israel. Jesus' mission is to Israel. However, Jesus' mission is not an exclusive one. Right from the beginning Jesus has been associated with gentiles. Gentiles were included in his genealogy. The wise men from the East come to honour Jesus while the Jewish leaders would not. Along the way many gentiles step into the way of Jesus, like the Canaanite women and the Roman centurion. The horizon of Matthew is broadened to include gentiles along with Jews. The Matthean community welcomed and expected converts from all nations. This created much tension with the synagogue where Jews strived to uphold their exclusiveness within a community that was overwhelmed by Hellenism.

\section{BIBLIOGRAPHY}

ARISTOTLE

Ars Rhetorica. (English translation, Loeb Classical Library. Cambridge: Harvard University Press, 1926.)

Augustine

De consensus Evangelistarum. Grand Rapids: Eerdmans. (English translation in Nicene and Post-Nicene Fathers, volume 6, 1904.) 
BAUCKHAM, R.J.

1998. For whom were the Gospels written? In: R.J. Bauckham (ed.), The gospel for all Christians: rethinking the Gospel audience (Grand Rapids: Eerdmans), pp. 9-48.

BOCK, D.L.

2002. Studying the historical Jesus. A guide to sources and methods. Grand Rapids: Baker Academic.

BRANDON, S.G.F.

1951. The fall of Jerusalem and the Christian church. London: SPCK.

BurRIDGE, R.A.

1994. Four Gospels, one Jesus? Grand Rapids: Eerdmans.

1995. What are the Gospels? A comparison with Graeco-Roman biography. Cambridge: Cambridge University Press.

1998. About people, by people, for people: Gospel genre and audiences. In: R.J. Bauckham (ed.), The gospel for all Christians: rethinking the Gospel audience (Grand Rapids: Eerdmans), pp. 113-146.

Chrysostom, J.

Homilies on the Gospel according to St. Matthew. Grand Rapids: Eerdmans. (English translation of Commentarius in sanctum Matthaeum Evangelistam in Nicene and PostNicene Fathers, volume 10.)

Clark, K.W.

1947. The gentile bias in Matthew. Journal of Biblical Literature 66:165-172.

DANIÉlOU, J.

1964. A history of early Christian doctrine. London: Darton, Longman \& Todd.

Davies, W.D. \& Allison, D.C.

2004. Matthew 1-7. London \& New York: T. \& T. Clark. International Critical Commentary.

DERRETT, J.D.

1975. Further light on the narratives of the nativity. Novum Testamentum 17:81-108.

DUNN, D.G.

1980. Christology in the making. London \& Philadelphia: Westminster.

1991. The parting of the ways between Christianity and Judaism and their significance for the character of Christianity. Philadelphia: Trinity Press International.

FRANCE, R.T.

1998. Matthew, evangelist and teacher. Illinois: Intervarsity Press. New Testament Profiles.

HAGNER, D.A.

1993. Matthew 1-1. Dallas: Word Books. Word Biblical Commentary 33A. 
HARE, D.R.A.

1967. The theme of Jewish persecution of Christians in the Gospel according to St. Matthew. Cambridge: University Press.

HORBURY, W.

1982. The benediction of the minim and early Jewish Christian controversy. Journal of Theological Studies 33:19-61.

HuMMel, R.

1966. Die Auseinandersetzung zwischen Kirche und Judentum im Matthäusevangelium. München: Kaisar.

JEROME

Commentariorum in Matthaeum libri IV. New York: Hildesheim. (In volume 7 of D. Vallarsi, Opera omnia. Verona, 1769, pp. 1-244.)

KeENer, G.S.

1999. A commentary on the Gospel of Matthew. Michigan \& Cambridge: Eerdmans.

KILPATRICK, G.D.

1946. The origins of the gospel according to St. Matthew. Oxford: Clarendon.

LUZ, U.

1990. Matthew 1-7. A commentary. Edinburgh: T \& T Clark.

MiCHEL, O.

1950. Der Abschluss des Matthäusevangeliums. Evangelische Theologie 10:21-26.

MOHRLANG, R.

1984. Matthew and Paul: a comparison of ethical perspectives. Cambridge: Cambridge University Press.

Nepper-Christensen, P.

1958. Das Matthäusevangelium: ein Juden-christliches Evangelium? Aarhus: Universitetsforlaget.

RABINOWITZ, P.J.

1987. Before reading. Ithaca: Cornell University Press.

REPSCHINSKI, B.

2000. The controversy stories in the Gospel of Matthew: Their redaction, form and relevance for the relationship between the Matthean community and formative Judaism. Göttingen: Vandenhoeck \& Ruprecht.

2004. For He will save his people from their sins... (Mt. 1:21). A Christology for Christian Jews. Paper read at SNTS Barcelona.

SCHLATTER, A.

1963. Der Evangelist Matthäus. Stuttgart: Calwer Verlag.

STANTON, G.N.

1977. 5 Ezra and Matthian Christianity. Journal of Theological Studies 28:67-88.

1983. A Gospel for a new people: Studies in Matthew. Edinburgh: T \& T Clark. 
1992. Matthew's Christology and the parting of the ways. In: J.D.G. Dunn (ed.), The parting of the ways A.D. 70 to 135. The second Durham-Tübingen research symposium on earliest Christianity and Judaism. Durham, September 1989 (Tübingen: Mohr-Siebeck, WUNT 66), pp. 99-116.

STENDAHL, K.

1968. The school of St. Matthew, and its use of the Old Testament. Philadelphia: Fortress.

1995 [1960]. Quis et unde? An analysis of Matthew 1-2. In: G.N. Stanton (ed.), The interpretation of Matthew. Studies in New Testament interpretation (Edinburgh: T \& T Clark), pp. 69-80.

STRECKER, G.

1971. Der Weg der Gerechtigkeit. Untersuchung zur Theologie des Matthäus. Göttingen: Vandenhoeck \& Ruprecht.

STREETER, B.H.

1924. The Four Gospels: a study of origins. London: Macmillan.

VAN BRUGGEN, J.

1998. Christ on earth. The Gospel narratives as history. Michigan: Baker Books.

VERSTEEG, J.

1992. Evangelie in viervoud. Een karakteristiek van de vier evangeliën. Kampen: Kok.

VILJOEN, F.P.

2002. Jesus sonder Christus of Christus sonder Jesus? In die Skriflig 36(4):555-572. 2005. Jesus se onderrig van die Torah in die Bergrede as model vir ons navorsing en onderrig van die Nuwe Testament. Potchefstroom: Noordwes-Universiteit. Wetenskaplike Bydraes — Reeks H: Intreerede nr. 199.

VLEDDER, E-J.

1997. Conflict in the miracle stories: a socio-exegetical study of Matthew 8 and 9. Journal for the Study of the New Testament Supplementum 152.

Trefwoorde

Matteusgemeenskap

Evangelie as narratief

Joodse en Christelike

kontroversieverhale

Evangelie-inleiding

Joods-Christelik
Keywords

Matthean community

Gospel as narrative

Jewish and Christian

controversy stories

Gospel beginning

Jewish-Christian 